\title{
rRNA gene restriction patterns of Vibrio anguillarum serogroup $\mathrm{O} 1$
}

\author{
Karl Pedersen, Jens Laurits Larsen \\ Royal Veterinary and Agricultural University, Department of Veterinary Microbiology, Section of Fish Diseases, \\ Bülowsvej 13, DK-1870 Frederiksberg C, Denmark
}

\begin{abstract}
Forty-four strains of Vibrio anguillarum serogroup O1 isolated from dead or diseased fish from several, mainly European, countries were selected for rRNA gene restriction pattern analysis. With HindIII, 6 different ribotypes were detected of which 1 profile was dominant with respect to geographical distribution as well as fish species. Also with EcoRI, 6 patterns were found; 1 profile was clearly dominant. The majority of strains belonging to the dominant HindIII profile also expressed the dominant EcoRI profile. It is concluded that ribotyping may be a valuable tool in epidemiological investigations and for research purposes within $V$. anguillarum serogroup 01 .
\end{abstract}

\section{INTRODUCTION}

Vibrio anguillarum is worldwide one of the major bacterial pathogens of various fish species, such as salmonids, turbot, cod, and eel. The disease is observed in cultured as well as feral fish. Vibriosis usually develops as an ulcerative septicaemia, and the causative agent can be isolated from all organs of the diseased fish (Austin \& Austin 1987).

A serotyping system developed for Vibrio anguillarum has shown that the vast majority of strains isolated from diseased or dead fish belong to the serogroups O1 and O2 (Sørensen \& Larsen 1986) while the remaining serogroups seem to be associated mainly with the environment and are usually non-pathogenic to fish (Toranzo \& Barja 1990). In salmonids, O1 seems to be the most important serogroup, while serogroup $\mathrm{O} 2$ is the one most frequently isolated from non-salmonid fishes (Larsen et al. 1988). Strains from serogroup O1 constitute a more homogeneous group than strains from $\mathrm{O} 2$ with respect to biochemical properties, plasmid content (Larsen 1990), and immunological properties (Bolinches et al. 1990). The purpose of the present study was to examine genetic differences in a homogeneous group of $V$. anguillarum $\mathrm{O} 1$ strains by means of ribotyping. This may be of great value as a supplement to traditional typing methods in epidemiological studies of vibriosis. Restriction enzyme analyses
(REA) and ribotyping are new tools for typing of bacteria and have been used in a number of bacterial species /Grimont \& Grimont 1986, Irino et al. 1988, Saunders et al. 1988, Owen 1989, Andersen \& Saunders 1990). This paper presents evidence that ribotyping may be used to subtype $V$. anguillarum $\mathrm{O} 1$ strains.

\section{MATERIALS AND METHODS}

Bacterial strains. Forty-four strains of Vibrio anguillarum serogroup $\mathrm{O} 1$ were investigated. Thirty-nine of the strains were isolated from salmonids, 4 from turbot, and 1 from ayu. The strains were all isolated from diseased or dead fish as described in Table 1. The first 10 strains listed in Table 1 were all isolated from the same fish farm during a 1 yr period. The remaining strains were considered epidemiologically unrelated. All strains were taken from the culture collection of the laboratory and had been isolated in our laboratory or had been received as gifts from other laboratories. Bacteria were biochemically characterized and identified as described by Sørensen \& Larsen (1986).

Serological test. OK-antisera against formalin-killed bacteria were raised in rabbits and $\mathrm{O}$-serotyping was carried out using the slide agglutination test as described by Sørensen \& Larsen (1986). 
Table 1. Vibrio anguillarum serotype $\mathrm{O} 1$ used in the experiments and their ribotype profiles with respect to the restriction enzymes HindIII and EcoRI

\begin{tabular}{|c|c|c|c|c|}
\hline \multirow[t]{2}{*}{ Strain } & \multirow[t]{2}{*}{ Fish species } & \multirow[t]{2}{*}{ Country } & \multicolumn{2}{|c|}{ Ribotype, profile number } \\
\hline & & & HindIII & EcoRI \\
\hline 89-12-199 & Oncorhynchus mykiss & Denmark & 1 & A \\
\hline $89-12-201$ & Oncorhynchus mykiss & Denmark & 1 & $\mathrm{~B}$ \\
\hline $89-12-204$ & Oncorhynchus mykiss & Denmark & 1 & $\mathrm{~A}$ \\
\hline $89-12-205$ & Oncorhynchus mykiss & Denmark & 1 & A \\
\hline $89-12-206$ & Oncorhynchus mykiss & Denmark & 1 & $\mathrm{~A}$ \\
\hline $90-11-281$ & Oncorhynchus mykiss & Denmark & 1 & A \\
\hline $90-11-286$ & Oncorhynchus mykiss & Denmark & 2 & $E$ \\
\hline $90-11-287$ & Oncorhynchus mykiss & Denmark & 1 & $\bar{A}$ \\
\hline $90-11-305$ & Oncorhynchus mykiss & Denmark & 1 & A \\
\hline $90-12-319$ & Oncorhynchus mykiss & Denmark & 1 & A \\
\hline $6018 / 1$ & Oncorhynchus mykiss & Denmark & 1 & A \\
\hline $820616-1 / 2$ & Oncorhynchus mykiss & Denmark & 1 & A \\
\hline $820616-1 / 5$ & Oncorhynchus mykiss & Denmark & 1 & A \\
\hline $820617-1 / 6$ & Oncorhynchus mykiss & Denmark & 1 & A \\
\hline $820617-1 / 8$ & Oncorhynchus mykiss & Denmark & 1 & A \\
\hline $820721-1 / 11$ & Oncorhynchus mykiss & Denmark & 1 & A \\
\hline $830407-1 / 7$ & Oncorhynchus mykiss & Denmark & 1 & A \\
\hline $830407-1 / 9$ & Oncorhynchus mykiss & Denmark & 1 & A \\
\hline $830419-1 / 2$ & Oncorhynchus mykiss & Denmark & 1 & A \\
\hline $830419-1 / 6$ & Oncorhynchus mykiss & Denmark & 1 & A \\
\hline $830422-1 / 1$ & Oncorhynchus mykiss & Denmark & 1 & A \\
\hline $1359 \mathrm{~A}$ & Oncorhynchus mykiss & Italy & 3 & A \\
\hline 1692 & Oncorhynchus mykiss & Italy & 3 & A \\
\hline Т 246 & Oncorhynchus mykiss & England & 1 & $\mathrm{~B}$ \\
\hline VA 12 & Oncorhynchus mykiss & Canada & 4 & $\mathrm{C}$ \\
\hline $408 \mathrm{~F}$ & Oncorhynchus mykiss & France & 5 & $\mathrm{C}$ \\
\hline NCMB 2129 & Oncorhynchus mykiss & Norway & 1 & $\mathrm{~A}$ \\
\hline N 1803 & Oncorhynchus mykiss & Norway & 1 & A \\
\hline $91-7-151$ & Oncorhynchus mykiss & Norway & 1 & $\mathrm{~A}$ \\
\hline $91-8-198$ & Oncorhynchus mykiss & Norway & 1 & A \\
\hline $91-8-199$ & Oncorhynchus mykiss & Norway & 1 & A \\
\hline $87-9-117$ & Oncorhynchus mykiss & Finland & 1 & $A$ \\
\hline $51 / 82 / 2$ & Oncorhynchus mykiss & Germany & 1 & $A$ \\
\hline N 1793 & Salmo salar & Norway & 1 & A \\
\hline $87-9-116$ & Salmo salar & Finland & 1 & A \\
\hline Т 265 & Salmo salar & England & 1 & $\mathrm{~B}$ \\
\hline VA 41 & Salmo salar & Canada & 1 & $\mathrm{C}$ \\
\hline RG 75-834 & Oncorhynchus kisutsch & USA & 1 & $\mathrm{D}$ \\
\hline $53-507$ & Oncorhynchus kisutsch & USA & $\hat{1}$ & $\mathrm{~F}$ \\
\hline $\mathrm{R} 62$ & Scophthalmus maximus & Spain & 1 & A \\
\hline R 73 & Scophthalmus maximus & Spain & 1 & A \\
\hline $91-7-154$ & Scophthalmus maximus & Denmark & 6 & A \\
\hline $91-8-178$ & Scophthalmus maximus & Denmark & 6 & A \\
\hline PT 213 & Plecoglossus altivelis & Japan & 1 & $\mathrm{~B}$ \\
\hline
\end{tabular}

Isolation of total DNA. Total bacterial DNA was isolated essentially using the method of Saunders et al. (1988). Briefly, $1.5 \mathrm{ml}$ of an overnight broth culture grown in brain heart infusion broth (BHI) (Difco) at $20^{\circ} \mathrm{C}$ was harvested by centrifugation in a microfuge tube, resuspended in $500 \mu \mathrm{l}$ Tris: ethylenediaminetetraacetate (EDTA) $50: 50 \mathrm{mM}, \mathrm{pH} 8.0$, and lysed by addition of $20 \mu \mathrm{l} 10 \%$ sodium dodecyl sulphate (SDS). The lysates were extracted with phenol and phenol: chloroform: isoamylalcohol $25: 24: 1$, precipitated with isopropanol, washed twice with $70 \%$ ethanol, and resuspended in $45 \mu \mathrm{l}$ Tris: EDTA $10: 1 \mathrm{mM}, \mathrm{pH} 7.6$. Concentration of DNA in lysates was estimated by the ethidium bromide agarose method (Silhavy et al. 1984) using herring sperm DNA as standard.

Restriction enzyme digestion. Five $\mu \mathrm{l}$ corresponding to 5 to $10 \mu \mathrm{g}$ of the total DNA solutions was digested with the restriction enzymes HindIII, PstI, ECoRI, SmaI, BamHI, BclI, Sau3A, AvaI, Ncil, and Haelli (Boehringer, Mannheim, Germany) according to the instructions of the manufacturer. Digested DNA was precipitated with $22 \mu \mathrm{l} 7.5 \mathrm{M}$ ammonium acetate and $130 \mu \mathrm{l}$ 
$96 \%$ ethanol, centrifuged, and resuspended in $20 \mu \mathrm{l}$ distilled water. Ten $\mu \mathrm{l}$ loading buffer (EDTA $2 \mathrm{mM} \mathrm{pH}$ 8.0 , bromophenol blue $0.1 \%$, glycerol $30 \%$ ) was then added to the resuspended material and the mixture was subjected to electrophoresis in $0.8 \%$ agarose gels (Litex LSL) in TAE (Tris $40 \mathrm{mM}$, sodium acetate $5 \mathrm{mM}$, EDTA $1 \mathrm{mM}$ ) buffer, pH 7.8. Subsequently, gels were stained with ethidium bromide $2 \mu \mathrm{g} \mathrm{ml}^{-1}$ (Sigma) and photographed at $254 \mathrm{~nm}$ UV transillumination.

Southern blotting and ribotyping. Following separation by electrophoresis, DNA fragments were transferred to a nylon hybridization membrane (Hybond-N, Amersham) and fixed to the membrane by incubation at $80^{\circ} \mathrm{C}$ for $3 \mathrm{~h}$. Southern blots were hybridized overnight at $56{ }^{\circ} \mathrm{C}$ using a digoxigenin-labeled probe complementary to $16 \mathrm{~S}$ and $23 \mathrm{~S}$ rRNA of $E$. coli (Boehringer). Labeled fragments were visualized by incubation of the membranes with peroxidase-labeled anti-digoxigenin immunoglobulin (Boehringer) followed by the addition of nitroblue tetrazolium and 5-bromo-4-chloro-3-indolyl-phosphate (X-phosphate) (Boehringer).

\section{RESULTS}

All Vibrio anguillarum strains in the study reacted with $\mathrm{O} 1$ antiserum but not with antisera against any of the serotypes $\mathrm{O} 2$ to $\mathrm{O} 10$.

By restriction endonuclease analysis (REA) of DNA from Vibrio anguillarum 01 , differences between strains could be detected but the patterns were very difficult to interpret due to the presence of several closely positioned bands (data not shown).

DNA from a few strains was digested with an array of restriction enzymes and hybridized with the digoxigenin-labeled probe. The results for the 6018/1 strain after digestion with 7 different enzymes are shown in Fig. 1.

Digestion of DNA with HindIII followed by hybridization with the digoxigenin-labeled probe yielded 15 to 17 well-separated fragments and this enzyme was therefore chosen for use with all strains. Results of ribotyping using EcoRI as the restriction enzyme were more difficult to interpret because the number of bands was lower - usually 7 - and they were positioned more closely to each other. However, EcoRI was also used on all strains.

A total of 6 different $r$ RNA gene restriction patterns were detected with HindIII (Fig. 2). Each ribotype was given an arbitrary number from 1 to 6 . Profile 1 was clearly dominant (Table 1). This ribotype was found in Vibrio anguillarum isolates from rainbow trout in Denmark, rainbow trout and salmon from Norway, rainbow trout and salmon from Finland, rainbow trout

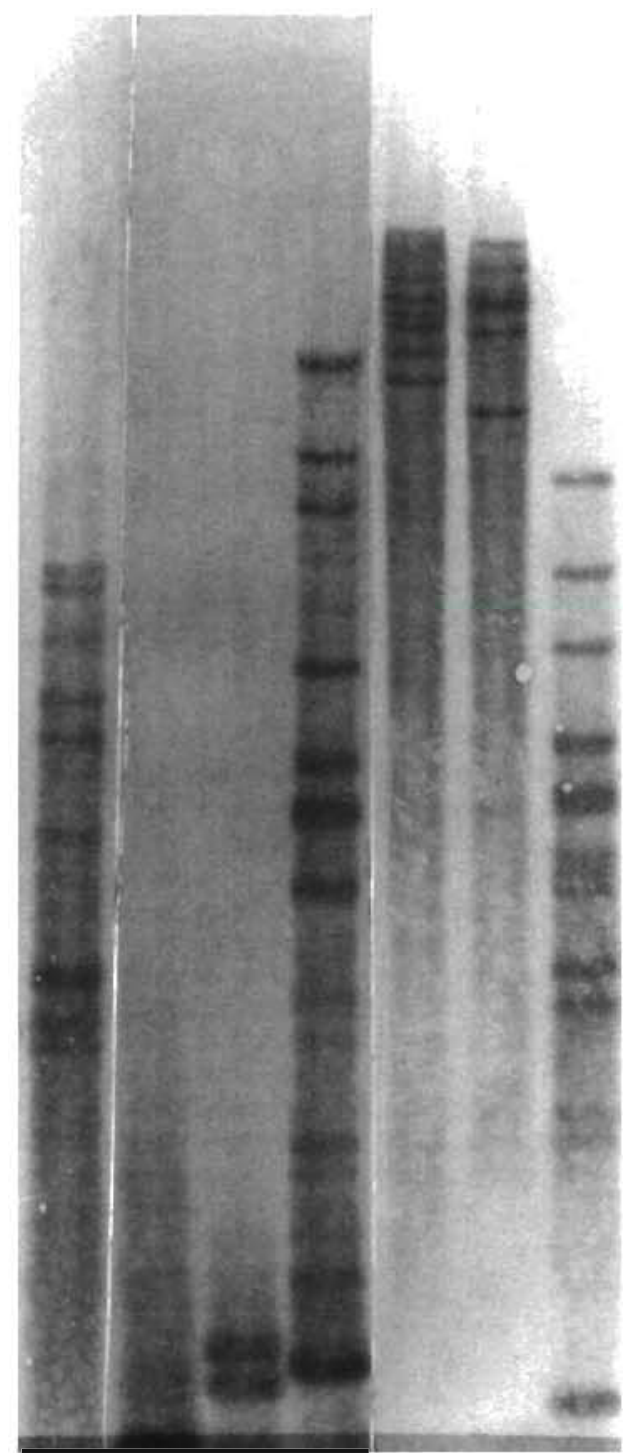

Fig. 1. Vibrio anguillarum. Ribotyping of $6018 / 1$ using 7 different restriction enzymes. Lane 1. Ncil; lane 2: Sau3A; lane 3: Haelli; lane 4: AvaI; lane 5: PstI; lane 6: EcoRI; lane 7: HindIII

and salmon from England, turbot from Spain, salmon from Canada, coho salmon from the USA, and ayu from Japan. Profile 2 was found in only 1 isolate, a strain from a rainbow trout in Denmark. Profile 3 was detected in 2 strains, both of them from rainbow trout from Italy. Profiles 4 and 5 were each detected in only 1 strain isolated from rainbow trout from Canada and France, respectively, while Profile 6 was found in isolates from 2 Danish turbot isolated from 2 different fish farms.

Ribotyping using HindIII as restriction enzyme showed reproducible results. When DNA from the same strain was isolated and digested repeatedly, patterns were always identical.

With EcoRI, 6 different profiles could also be distin- 


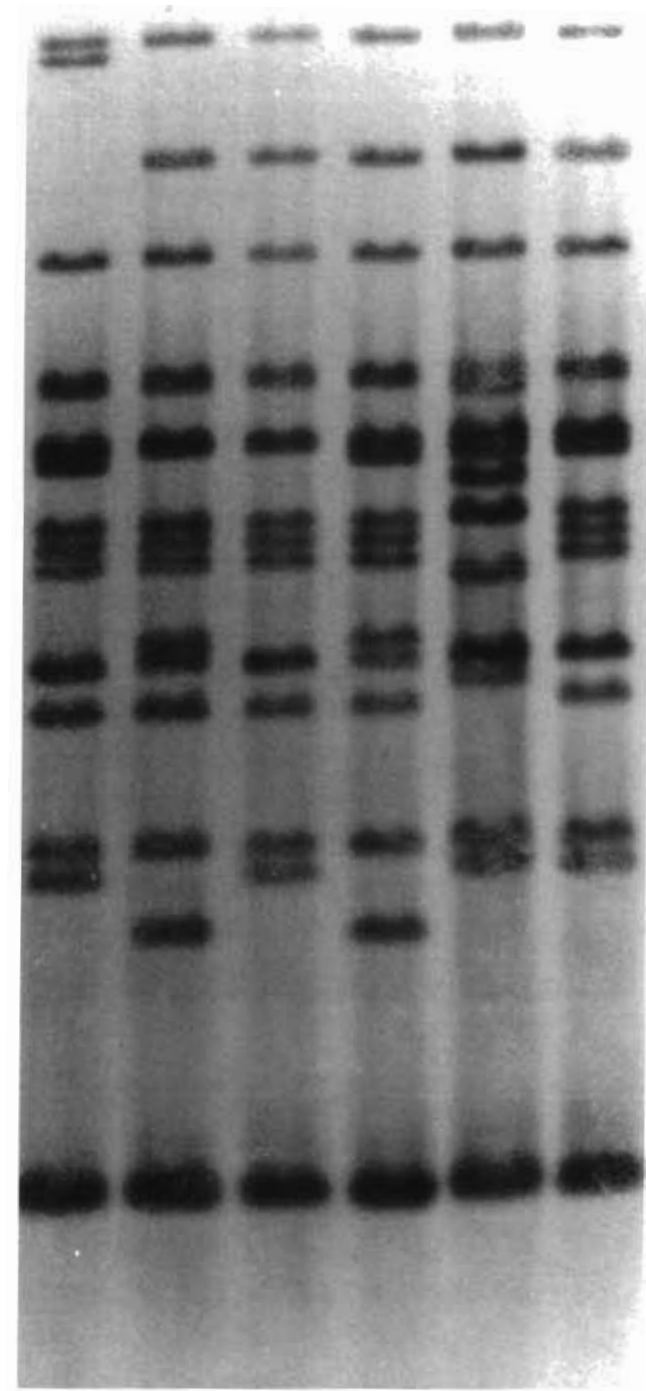

Fig. 2. Vibrio anguillarum. Ribotyping of serogroup $\mathrm{O} 1$ strains using HindIII as the restriction enzyme. Six different profiles were detected. Lane 1: strain 91-7-154, profile 6; lane 2: strain $408 \mathrm{~F}$, profile 5 ; lane 3 : strain VA 12, profile 4; lane 4 : strain 1359 A, profile 3; lane 5: strain 90-11-286, profile 2; and lane 6 : strain $6018 / 1$, profile 1

guished (Fig. 3). These profiles were arbitrarily designated by letters from A to F. Strains showing the same HindII profile usually also shared the same EcoRI profile (Table 1). Thus, strains belonging to HindIII profile 1 almost all possessed EcoRI profile A. However, among the HindIII profile 1 strains, the 2 strains from England both belonged to EcoRI profile B together with the Japanese strain from ayu and the Danish 89-12-201 strain. The 53-507 strain isolated from coho salmon in the USA had a unique EcoRI profile, F, although it had the common HindIII profile 1 . The 2 strains with HindIII profile 6 both belonged to EcoRI profile $A$ and were both isolated from turbot but from
2 different fish farms. The only strain with HindIII profile 2 also had a unique EcoRI profile, E. Both Canadian strains, VA 12 and VA 41, although they were isolated from 2 different fish species and had different HindIII profiles -4 and 1, respectively - shared the same EcoRI profile, $C$, together with the French strain with HindIII profile 5. The only strain with ECoRI profile D was RG 75-834 isolated from a coho salmon from the USA. This strain expressed HindIII profile 1.

\section{DISCUSSION}

Typing of Vibrio anguillarum is usually performed using biochemical and serological methods and in most cases these techniques yield a characterization of the strain. On some occasions, however, it is desirable to be able to subtype otherwise identical isolates for epidemiological or research purposes. A phage typing system has not been developed for $V$. anguillarum. Therefore, molecular biological techniques may be of some value. Chromosomal DNA-DNA hybridization experiments have been conducted (Schiewe \& Crosa 1981). These authors demonstrated marked differences between biotypes 1 and 2 while strains belonging to the same biotypes showed a high degree of homology. Tsai et al. (1990) examined differences between various Vibrio species by restriction endonuclease analysis (REA). Each species was shown to possess a distinct fingerprint pattern. Furthermore, within $V$. anguillarum different REA patterns were demonstrated. The authors therefore conclude that REA is a potential tool for epidemiological studies of Vibrio species in fish, shrimp, and shellfish. Wards et al. (1991) characterized $V$. ordalii isolates from New Zealand by plasmid profiling and REA. They found that all isolates from New Zealand possessed identical REA patterns, but this pattern was substantially different from a $V$. anguillarum type strain. Rehnstam et al. (1989) found by rRNA sequencing that small but significant differences could be detected between 7 different $V$. anguillarum strains and concluded that typing based on RNA was possible. They also constructed an RNA probe from $16 \mathrm{~S}$ rRNA specific for $V$. anguillarum.

Restriction enzyme analyses have also been performed on plasmid DNA in a number of species, including Vibrio anguillarum (Olsen \& Larsen 1990). However, this method only characterizes the plasmids and not the host, and since not all $V$. anguillarum strains carry plasmids (Larsen 1990) or because plasmids may be lost, not all strains are typable. Some authors have suggested the existence of 2 distinct subpopulations of $V$. anguillarum serogroup 01 : strains with and strains without the pJM1 virulence plasmid (Larsen et al. 1988). 


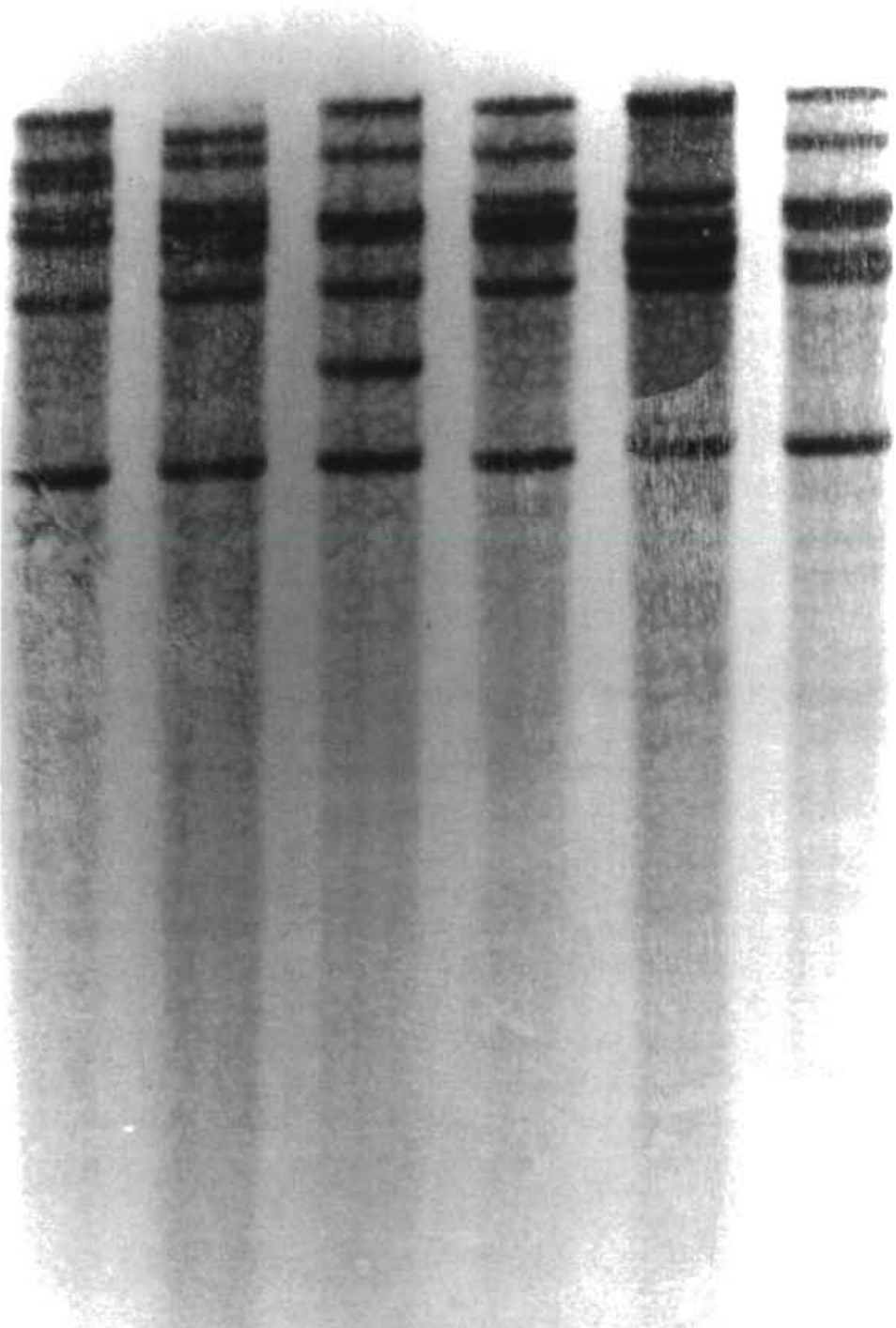

Fig. 3. Vibrio anguillarum. Ribotyping of serogroup O1 using EcoRI as the restriction enzyme. Six different profiles were detected. Lane 1. strain RG

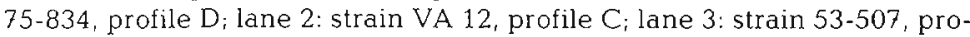

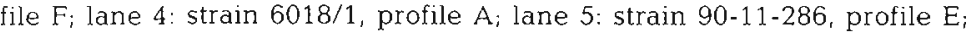
and lane 6 : strain $89-12-201$, profile $B$

Restriction enzyme digests of total DNA from bacteria may be very difficult to evaluate due to the usually large number of closely spaced bands that result. The problem with interpretation may be solved by the use of probes to pinpoint specific DNA fragments. rRNA gene restriction patterns have proved to be of great value for the identification and/or molecular epidemiological characterization of homogeneous groups of bacteria (Grimont \& Grimont 1986, Irino et al. 1988. Saunders et al. 1988, Andersen \& Saunders 1990, Moyer et al. 1992). rRNA genes are highly conserved genes - more so than the rest of the genome - and are present in multiple copies in the bacterial chromosome. The method is therefore sensitive and has con- siderable power to discriminate between closely related strains. Further, a single probe (rRNA from E. coli) is applicable to a large number of bacterial species (Grimont \& Grimont 1986, Saunders et al. 1988, Stull et al. 1988). This work describes the application of ribotyping to strains of Vibrio anguillarum serogroup $\mathrm{O} 1$ as a potential tool for further identification and epidemiological characterization. Six different ribotypes were identified with HindIII. Profile 1 was the most widely distributed, both geographically and with respect to fish species. While this profile was detected in isolates of $V$. anguillarum worldwide, and in various fish species, the other profiles were found in strains from only 1 or 2 countries and in 1 or 2 fish species. With EcoRI, 6 different ribotypes were also distinguished. Most of the strains examined belonged to HindIII profile 1 and EcoRI profile A.

From one particular Danish fish farm 10 different strains from rainbow trout were examined. These 10 strains were shown to belong to 3 different ribotypes. This farm had experienced repeated outbreaks of vibriosis for over a year in spite of vaccination. Our results therefore suggested that 3 (or more) Vibrio anguillarum serotype 01 clones were involved in these outbreaks. In future outbreaks, ribotyping of isolated strains may therefore be a tool for identification of the source of infection. Also, possible variation in antigenicity between the different ribotypes should be investigated.

The strains included in the present study were mainly European isolates and thus our results may not be representative of the extent of the variability that occurs within the O1 serogroup. However, despite this shortcoming, the results indicate that this technique has potential for epidemiological investigations within the Vibrio anguillarum $\mathrm{O} 1$ serogroup.

Acknowledgements. This work was supported by the Danish Agricultural and Veterinary Research Council grant no. 13-4710-1 and 13-4508-1 NMP. The technical assistance of Mrs Maj-Britt Højgård is gratefully acknowledged.

\section{LITERATURE CITED}

Andersen, J. K., Saunders, N. A. (1990). Epidemiological typing of Yersinia enterocolitica by analysis of restriction length polymorphisms with a cloned ribosomal RNA gene. J. med. Microbiol. 32: 179-187

Austin, B., Austin, D. A. (1987). Bacterial fish pathogens: dis- 
ease in farmed and wild fish. Ellis Horwood Ltd, Chichester

Bolinches, J., Lemos, M. L., Fouz, B., Cambra, M., Larsen, J. L., Toranzo, A. E. (1990). Serological relationship among Vibrio anguillarum strains. J. aquat. Anim. Health 2: $21-29$

Grimont, F., Grimont, P. A. D. (1986). Ribosomal ribonucleic acid gene restriction patterns as potential taxonomic tools. Ann. Inst. Pasteur/Microbiol. 137B: 165-175

Irino, K., Grimont, F., Casin, I., Grimont, P. A. D., The Brazilian Purpuric Fever Study Group (1988). rRNA gene restriction patterns of Haemophilus influenzae biogroup aegyptius strains associated with Brazilian purpuric fever. J. clin. Microbiol. 26: 1535-1538

Larsen, J. L. (1990). Vibrio anguillarum. Characterization, ecology, and pathogenicity. Dissertation, DSR Press, Copenhagen

Larsen, J. L., Rasmussen, H. B., Dalsgaard, I. (1988). Study of Vibrio anguillarum strains from different sources with emphasis on ecological and pathobiological properties. Appl. environ. Microbiol. 54: 2264-2267

Moyer, N. P., Martinetti, G., Lüthy-Hottenstein, J., Altwegg, M. (1992). Value of rRNA gene restriction patterns of Aeromonas spp. for epidemiological investigations. Curr. Microbiol. 24:15-21

Olsen, J. E., Larsen, J. L. (1990). Restriction fragment length polymorphism of the Vibrio anguillarum serovar 01 virulence plasmid. Appl. environ. Microbiol. 56: 3130-3132

Owen, R. J. (1989). Chromosomal DNA fingerprinting - a new method of species and strain identification applicable to microbial pathogens. J. med. Microbiol. 30: 89-99

Rehnstam, A.-S., Norquist, A., Wolf-Watz, H., Hagström, $\AA$.

Responsible Subject Editor: T: Evelyn, Nanaimo, B.C., Canada
(1989). Identification of Vibrio anquillarum in fish by using partial 16S rRNA sequences and a specific 16S rRNA oligonucleotide probe. Appl. environ. Microbiol. 55: $1907-1910$

Saunders, N. A., Harrison, T. G., Kachawalla, N., Tailor, A. G. (1988). Identification of species of the genus Legionella using cloned rRNA gene from Legionella pneumophila. J. gen. Microbiol. 134: 2363-2374

Schiewe, M. H., Crosa, J. H. (1981). Molecular characterization of Vibrio anguillarum biotype 2. Can. J. Microbiol. 27 : $1011-1018$

Silhavy, T J., Berman, M. L., Enquist, L. W. (1984). Experiments with gene fusions. Procedure 25, Cold Spring Harbour Laboratory, NY, p. 138-139

Sørensen, U. B. S., Larsen, J. L. (1986). Serotyping of Vibrio anguillarum. Appl. environ. Microbiol. 51: 593-597

Stull, T., LiPuma, J. J., Edlind, T. D. (1988). A broad-spectrum probe for molecular epidemiology of bacteria: ribosomal RNA. J. infect. Dis. 157: 280-286

Toranzo, A. E., Barja, J L. (1990). A review of the taxonomy and seroepizootiology of Vibrio anguillarum, with special reference to aquaculture in the northwest of Spain. Dis. aquat. Org. 9: 73-82

Tsai, H.-J., Yeh, M.-S., Song, Y.-L. (1990). Characterization of Vibrio species by using DNA fingerprinting techniques. Fish Pathol. 25: 201-206

Wards, B. J., Patel, H. H., Anderson, C. D., de Lisle, G. W. (1991). Characterization by restriction endonuclease analysis and plasmid profiling of Vibrio ordalii strains from salmon (Oncorhynchus tshawytscha and Oncorhynchus nerka) with vibriosis in New Zealand. N.Z. J. mar. Freshwat. Res. 25: 345-350

Manuscript first received: September 14, 1992

Revised version accepted: May 4, 1993 